\title{
RESPIRATORY PROPERTIES OF THE ARTERIAL BLOOD IN NOR- MAL MAN AND IN PATIENTS WITH DISEASE OF THE LIVER: POSITION OF THE OXYGEN DISSOCIATION CURVE
}

\author{
By ANCEL KEYS AND ALBERT M. SNELL \\ (From the Division of Biochemistry, The Mayo Foundation, and the Division of Medicine, The \\ Mayo Clinic, Rochester, Minn.)
}

(Received for publication July 21, 1937)

It is now generally agreed that the oxygen saturation of the arterial blood in normal man in rest at low altitudes is remarkably constant. Until recently, subnormal arterial saturations could almost invariably be traced to obvious pulmonary or cardiac disorders. Recently, however, it was noted that relative arterial unsaturation is common among patients with cirrhosis of the liver and other conditions involving severe parenchymatous hepatic damage (Snell (1)). In such cases, circulatory disturbances, ascites and edema did not appear to account for the unsaturation, and it was pointed out that the anoxemia in these cases must have resulted either from some interference with gas exchange in the lungs or from an abnormality of the blood itself. In the cases which came to necropsy, however, pathological changes in the lungs sufficient to account for the phenomenon were not seen, though minor alterations, for example, edema of the alveolar walls, could not be absolutely excluded.

By the process of elimination an alteration of the blood itself was suggested, and one of us (Snell (2)) produced evidence to indicate that the oxygen dissociation curve of the blood was abnormal in these cases of hepatic disease. Two major objections could be raised against the acceptance of this conclusion. In the first place, the dissociation curves had all been studied at constant partial pressure of carbon dioxide rather than at constant $\mathrm{pH}$; even in normal man this procedure may erroneously indicate alterations in the position of the oxygen dissociation curve and, in pathological conditions, such a method of comparison may lead to gross errors. In the second place, normal standards for the position of the oxygen dissociation curve, based on modern technic, had not yet been definitely established.

The present study is a reexxamination of the problem, with special emphasis on the question of the position of the oxygen dissociation curve. This point is particularly important because the fundamental constancy of the position of the oxygen dissociation curve of human blood at constant $\mathrm{pH}$ has been demonstrated in a wide variety of pathological conditions : in nephritis (3), pernicious anemia (4), diabetic coma (5), and in men acclimatized to chronic anoxemia (6).

\section{METHODS OF STUDY}

Blood sampling. All blood samples were drawn under oil from the brachial artery and were immediately heparinized under oil and stored at $0^{\circ} \mathrm{C}$. until analysis. At the time of blood sampling all patients were fasting and as nearly as possible in a state of basal rest.

Blood analysis. All analyses were done in duplicate by two independent analysts. Blood gases were determined by the standard Van Slyke methods within one hour after the blood was drawn. Barcroft tonometers of $300 \mathrm{cc}$. capacity were used for tonometry, equilibration being carried out for 20 minutes at $37.5^{\circ} \mathrm{C}$. The $\mathrm{pH}$ of the equilibrated blood was determined both by calculation and by the glass electrode. ${ }^{1}$ The method of Keys, Hall and Barron (6) was used for calculation of $\mathrm{pH}_{\mathrm{B}}(\mathrm{pH}$ of the plasma and whole blood) and $\mathrm{pH}_{\mathrm{c}}$ ( $\mathrm{pH}$ of the inside of the red cells). The glass electrode arrangement of Dill, Daly and Forbes (7) was used at $37.5^{\circ} \mathrm{C}$. with standard buffer calibrations before and after each day's experiments. Arterial plasma was separated by centrifugation under oil at $0^{\circ} \mathrm{C}$. Plasma chloride was estimated by the method of

$1 \mathrm{We}$ are greatly indebted to Dr. Marschelle H. Power for $\mathrm{pH}_{\mathrm{s}}$ measurements with the glass electrode. The following technicians participated in the analytical work reported in this paper: Miss Lucile Mahan (Van Slyke machines and general supervision of the analytical routine) and Misses Lyla Zick, Elizabeth McClay, Lenore Rivers, Catharine Ryan, and Charlotte Bradshaw. 
Keys (8) and total base by the electrodialysis method (9).

\section{Oxygen saturation of the arterial blood}

In normal man in rest at altitudes less than 1000 meters, the oxygen saturation of the arterial blood is generally reported by competent investigators to be within the range 93 to 97 per cent (10 to 17 inc.). With the most careful technic even these limits seem to be too wide, and the great majority of results fall within the range 94 to 96 per cent saturation. In Figure 1 is given the frequency distribution of oxygen saturation in the arterial blood of 87 normal subjects studied during the past three years at The Mayo Clinic and at the Fatigue Laboratory, Harvard University. Most of these normal subjects were men between the ages of 20 and 40 years, but both women and men outside this age range did not differ significantly from the main group in the degree of arterial saturation.

The oxygen saturation of the arterial blood of
61 patients with liver disease is also summarized in Figure 1. These cases include the 38 cases reported by one of us in 1935 (1). The great majority of these cases show very definite arterial unsaturation of a degree which must be presumed to have at least some influence on the general course of the patients' welfare.

The composition of the arterial blood of patients with liver disease

The data on some of the more significant properties of arterial blood of 14 patients with liver disease are summarized in Table I. With 3 exceptions (Cases 1,2, and 10), anemia was well marked, and the average oxygen capacity of the blood for the entire group was only about 80 per cent of normal. In 8 of the cases the arterial oxygen saturation was subnormal and, in 6 of these (Cases 4, 5, 8, 9, 11, and 13), this deficiency was superimposed on an anemia.

The carbon dioxide relations throw some light on the respiratory function in these patients. The

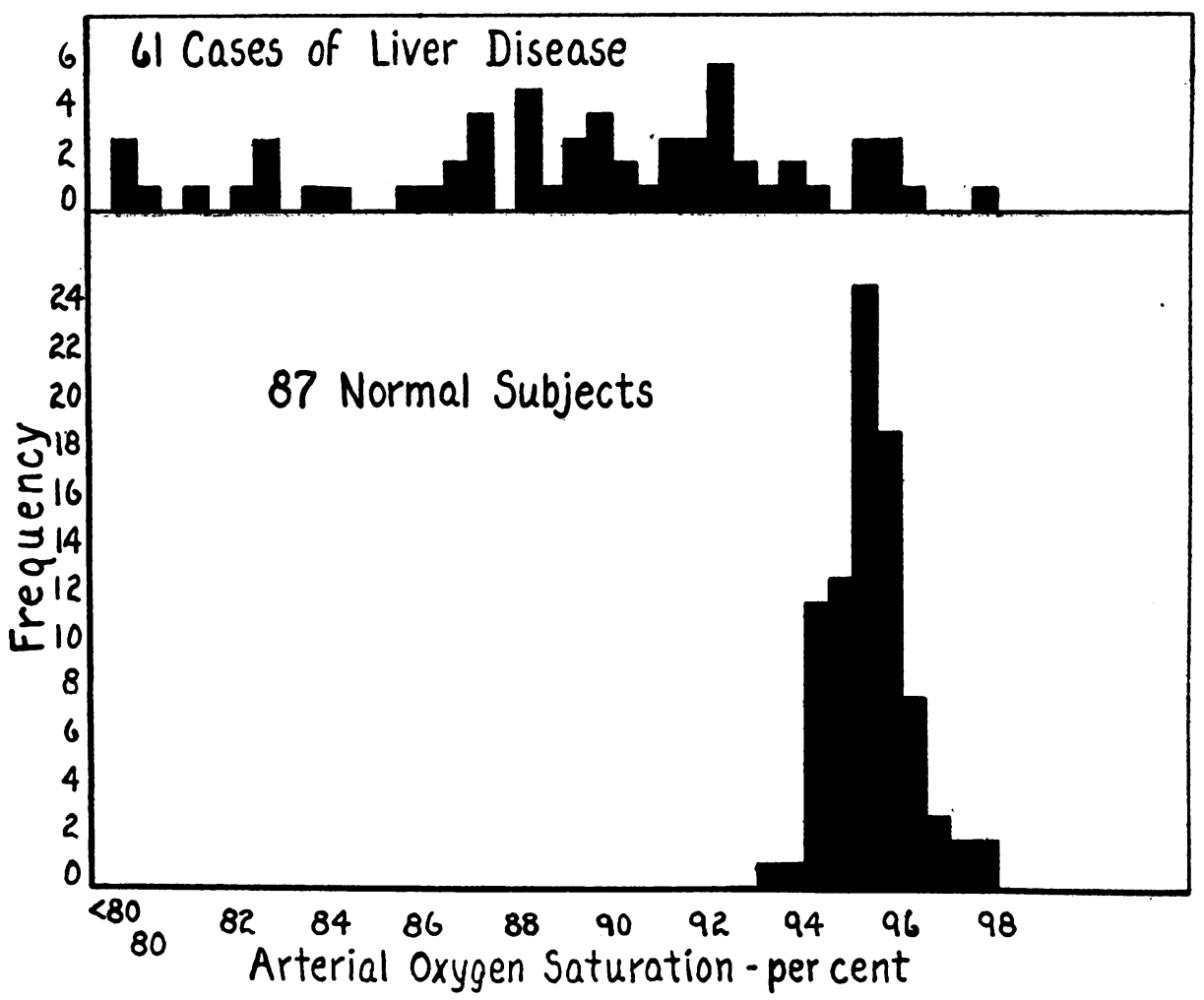

Fig. 1. Oxygen Saturation of the Arterial Blood of Normal Subjects and of Patients with Disease of the Liver 
TABLE I

Composition of the arterial blood in cases of liver disease

(Blood drawn in basal rest from the brachial artery. $\mathrm{T}_{40}=\mathrm{CO}_{2}$ content of oxygenated blood at $\mathrm{pCO}_{2}=40 \mathrm{~mm}$. and $37.5^{\circ} \mathrm{C}$.)

\begin{tabular}{|c|c|c|c|c|c|c|c|}
\hline \multirow{2}{*}{ Case } & \multirow{2}{*}{$\underset{\text { capacity }}{\mathrm{HbO}_{2}}$} & \multirow{2}{*}{$\begin{array}{l}\mathrm{O}_{2} \\
\text { saturation }\end{array}$} & \multirow{2}{*}{$\begin{array}{c}\mathrm{CO}_{2} \\
\text { content }\end{array}$} & \multirow{2}{*}{$T_{10}$} & \multicolumn{2}{|c|}{ Arterial plasma } & \\
\hline & & & & & $\mathrm{Cl}$ & Total base & \\
\hline 1 & $\begin{array}{l}\text { volumes } \\
\text { per cent } \\
19.6_{1}\end{array}$ & $\begin{array}{l}\text { per } \\
\text { cent } \\
92.3\end{array}$ & $\begin{array}{l}\text { volumes } \\
\text { per cent }\end{array}$ & $\begin{array}{l}\text { volumes } \\
\text { per cent }\end{array}$ & $\begin{array}{l}\text { m. eq. } \\
\text { per liter } \\
98.0\end{array}$ & $\begin{array}{l}\text { m. eq. } \\
\text { per liter } \\
138.6\end{array}$ & $\begin{array}{l}\text { Terminal acute portal cirrhosis with hepatic in- } \\
\text { sufficiency. }\end{array}$ \\
\hline $\begin{array}{l}2 \\
3 \\
4 \\
5\end{array}$ & $\begin{array}{l}20.7_{8} \\
17.5_{7} \\
16.7_{6} \\
11.5_{0}\end{array}$ & $\begin{array}{l}92.3 \\
95.6 \\
91.6 \\
89.6\end{array}$ & $\begin{array}{l}48.3 \\
49.8 \\
50.3 \\
45.9\end{array}$ & $\begin{array}{l}47.4 \\
49.0 \\
51.0 \\
50.5\end{array}$ & $\begin{array}{r}96.3 \\
105.0 \\
100.2\end{array}$ & $\begin{array}{l}146.7 \\
146.0 \\
142.4\end{array}$ & $\begin{array}{l}\text { Cirrhosis secondary to cardiac decompensation. } \\
\text { Hepatic cirrhosis (alcoholic history). } \\
\text { Hepatic cirrhosis (alcoholic history). } \\
\text { Terminal cirrhosis with hepatic insufficiency. Mili- }\end{array}$ \\
\hline $\begin{array}{l}6 \\
7 \\
8\end{array}$ & $\begin{array}{l}12.2_{9} \\
17.3_{2} \\
16.9_{6}\end{array}$ & $\begin{array}{l}95.6 \\
97.0 \\
93.7\end{array}$ & $\begin{array}{l}50.5 \\
47.4 \\
48.1\end{array}$ & $\begin{array}{l}49.7 \\
48.5 \\
49.0\end{array}$ & $\begin{array}{r}102.3 \\
98.7\end{array}$ & $\begin{array}{l}144.8 \\
142.4 \\
154.5\end{array}$ & $\begin{array}{l}\text { Cholangeitis, no serious liver damage. } \\
\text { Advanced hepatic cirrhosis. } \\
\text { Hepatitis of unknown etiology, with ascites and } \\
\text { iaundice. }\end{array}$ \\
\hline 9 & $12.9_{1}$ & 91.3 & 36.6 & 38.6 & 101.3 & 143.3 & $\begin{array}{l}\text { Advanced hepatic cirrhosis, with jaundice, ascites } \\
\text { and edema (alcoholic history). }\end{array}$ \\
\hline $\begin{array}{l}10 \\
11\end{array}$ & $\begin{array}{l}21.5_{8} \\
12.7_{9}\end{array}$ & $\begin{array}{l}98.5 \\
94.1\end{array}$ & $\begin{array}{l}36.7 \\
39.3\end{array}$ & $\begin{array}{l}36.0 \\
40.0\end{array}$ & 107.6 & 150.9 & $\begin{array}{l}\text { Terminal hepatic cirrhosis, with extreme ascites. } \\
\text { Cirrhosis with marked hepatic insufficiency and }\end{array}$ \\
\hline $\begin{array}{l}12 \\
13 \\
14\end{array}$ & $\begin{array}{r}9.0_{3} \\
16.6_{2} \\
14.6_{2}\end{array}$ & $\begin{array}{l}95.7 \\
91.5 \\
95.0\end{array}$ & $\begin{array}{l}48.1 \\
51.7 \\
42.1\end{array}$ & $\begin{array}{l}49.1 \\
49.2 \\
41.8\end{array}$ & $\begin{array}{l}107.8 \\
104.2\end{array}$ & & $\begin{array}{l}\text { Hepatic cirrhosis with ascites. } \\
\text { Hepatic cirrhosis with marked ascites. } \\
\text { Cholecystitis and secondary hepatic cirrhosis. }\end{array}$ \\
\hline Mean & 15.73 & 93.2 & 45.7 & 46.1 & 102.1 & 145.5 & \\
\hline
\end{tabular}

$\mathrm{CO}_{2}$ capacity of the whole blood was, on the average, slightly subnormal. The average of 46.1 volumes per cent at $\mathrm{pCO}_{2}=40 \mathrm{~mm}$. may be compared with an average of 48.8 obtained with 38 normal subjects in this laboratory and the average of 48.2 for repeated studies on 9 normals reported elsewhere (6). The deficiency of alkali reserve is more marked when the $\mathrm{CO}_{2}$ capacity of the plasma is studied. The average $\mathrm{CO}_{2}$ capacity of the plasma of patients with liver disease was 53.6 volumes per cent, as compared with $\mathbf{5 9 . 6}$ for the 38 normal subjects and 58.6 for the series of Keys and others (18).

The origin of this relative acidosis is not entirely clear. In a few cases, notably Cases 1, 5 , and 10 , there was a moderate acidemia $\left(\mathrm{pH}_{\mathrm{s}}\right.$ 0.03 to 0.05 more acid than normal), but in general the blood acidity was not far from normal. It will be noted that the average arterial $\mathrm{CO}_{2}$ content is also definitely subnormal. The $\mathrm{pCO}_{2}$ in the arterial blood averaged about $39.5 \mathrm{~mm}$. as compared with a normal average of about 41 to $42 \mathrm{~mm}$. If reliance can be placed on this small abnormality, it could be taken to indicate that, on the average, these patients were in a state of hy- perventilation. This in turn would also account for the observed moderate reduction in the alkali reserve. When the relative arterial unsaturation is also taken into account, the presumptive evidence in favor of hyperventilation is strong.

As might be expected, the mineral constituents of the plasma showed more than the usual amount of variation. The average chloride concentration is nearly normal. The average total base concentration may be approximately $5 \mathrm{~m}$.eq. below normal, but this may be accounted for by the hypoproteinemia that characterized the majority of these cases.

\section{Position of the oxygen dissociation curve of normal human blood}

The position of the oxygen dissociation curve of blood may be defined, with a precision sufficient for most purposes, by the partial pressure of oxygen required to produce half saturation (where $\mathrm{Hb}=\mathrm{HbO}_{2}$ ) at constant $\mathrm{pH}$ and temperature. It should be noted that, in whole blood, the effective $\mathrm{pH}$ is the $\mathrm{pH}$ of the interior of the red cells $\left(\mathrm{pH}_{\mathrm{c}}\right)$. The $\mathrm{pH}_{\mathrm{c}}$ cannot be measured directly, but it may be calculated with little error, 

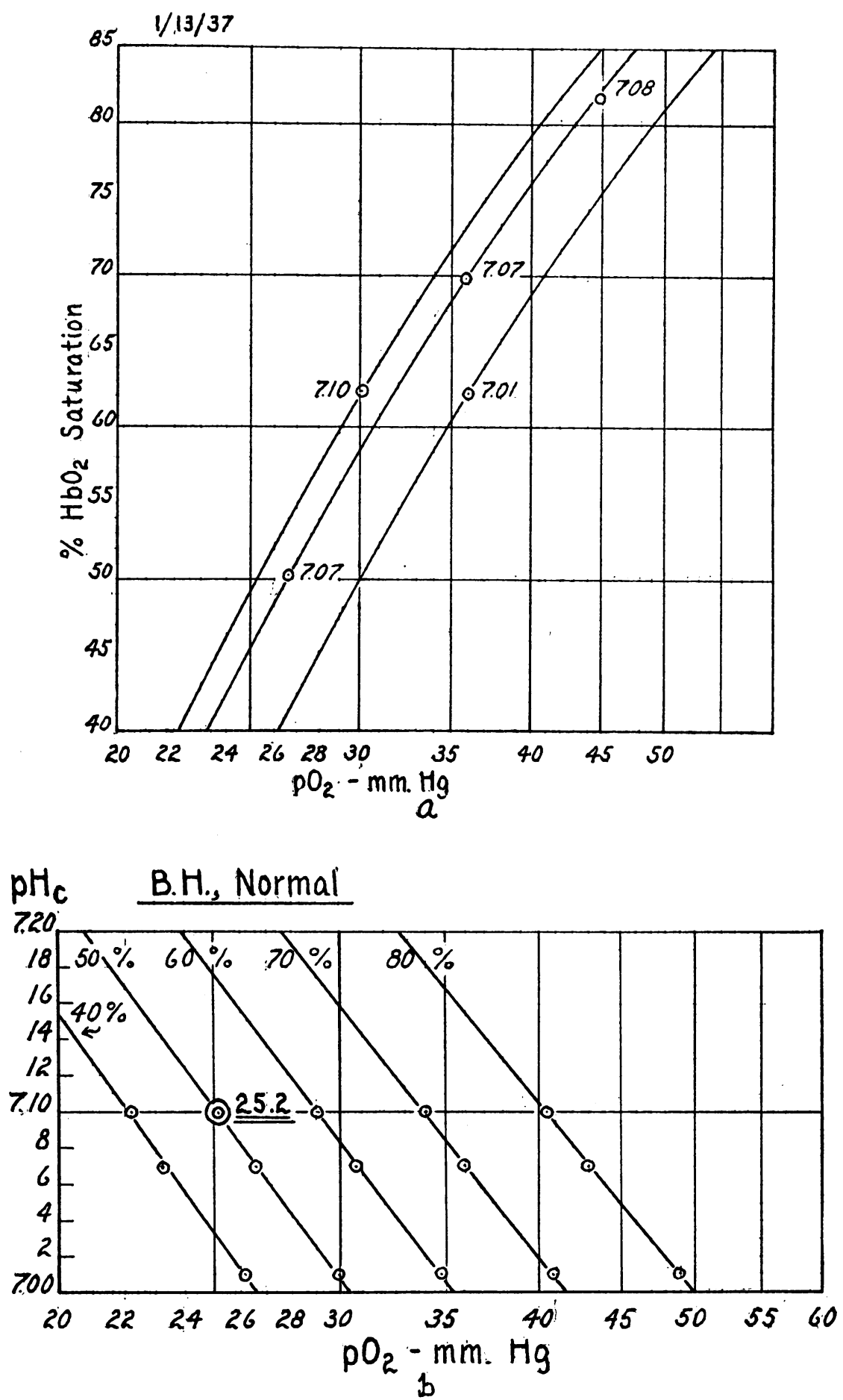

Fig. 2. Oxygen Dissociation Curves of Whole Blood of a Normal Man $a$, Plot of logarithm of partial pressure of oxygen $\left(\mathrm{pO}_{2}\right)$ against per cent of oxygen saturation; values of $\mathrm{pH}_{\mathrm{c}}$ are given alongside the determined points; and $b$, Plot of $\log \mathrm{pO}_{2}$ against $\mathrm{pH}_{\mathrm{c}}$ for oxygen saturations $40,50,60,70$, and 80 per cent. 
provided there is no abnormality in the ion balance between cells and plasma (6).

A more precise and detailed description of the position of the oxygen dissociation curve, including the effect of variation in $\mathrm{pH}_{c}$, emerges from the graphic treatment of the data, provided at least 5 tonometric equilibrations are done. An example of a useful graphic method is given in Figure 2. The plot of $\log \mathrm{pO}_{2}$ against per cent saturation has the advantage that, except at the upper and lower ends of the curve (above 80 per cent and below 20 per cent saturation), the curvature is slight and the iso- $\mathrm{pH}$ lines are closely parallel; over the range $\mathrm{pH}_{\mathrm{c}} 6.90$ to 7.30 , the plot of $\log \mathrm{pO}_{2}$ against $\mathrm{pH}$, for constant saturation, is a straight line.

Table II summarizes all the acceptable data available at present on the $\mathrm{pO}_{2}$ to give $\mathrm{Hb}$ $=\mathrm{HbO}_{2}\left(\mathrm{pH}_{\mathrm{c}} 7.10, \mathrm{~T} 37.5^{\circ} \mathrm{C}\right.$. $)$ in the blood of normal man. Each of the values listed in Table

TABLE II

Position of the oxygen dissociation curve of blood of normal man

(Partial pressure of oxygen $\left(\mathrm{pO}_{2}\right)$, in $\mathrm{mm}$. $\mathrm{Hg}$ required to give 50 per cent saturation $\left(\mathrm{Hb}=\mathrm{HbO}_{2}\right.$ ) at $\mathrm{pH}_{c} 7.10$ and $37.5^{\circ}$ C. Data from Dill, and others (19); Keys, and others (6), and present results.)

\begin{tabular}{|c|c|c|c|c|c|c|c|}
\hline \multirow{2}{*}{\multicolumn{2}{|c|}{$\underset{(19)}{\text { Dill and others }}$}} & \multicolumn{4}{|c|}{ Keys and others (6) } & \multirow{2}{*}{\multicolumn{2}{|c|}{ Present series }} \\
\hline & & \multicolumn{2}{|c|}{$\begin{array}{c}\text { Expedition } \\
\text { members }\end{array}$} & \multicolumn{2}{|c|}{$\begin{array}{l}\text { Chileans at } \\
5340 \mathrm{~m} \text {. }\end{array}$} & & \\
\hline Subject & $\mathrm{pO}_{2}$ & Subject & $\mathrm{pO}_{2}$ & Subject & $\mathrm{pO}_{2}$ & Subject & $\mathrm{pO}_{2}$ \\
\hline $\begin{array}{l}\mathbf{P} \\
\text { F } \\
\text { O } \\
\text { D } \\
\text { T } \\
\text { E } \\
\text { BR } \\
\text { BO }\end{array}$ & $\begin{array}{l}m m . \mathrm{Hg} \\
27.2 \\
28.2 \\
27.0 \\
28.2 \\
26.9 \\
25.6 \\
25.7 \\
26.6\end{array}$ & $\begin{array}{l} \\
\text { ESGB } \\
\text { EHC } \\
\text { DBD } \\
\text { GTE } \\
\text { WHF } \\
\text { FGH } \\
\text { AK } \\
\text { RAMC } \\
\text { JHT }\end{array}$ & \begin{tabular}{|l|}
$m m . H g$ \\
25.1 \\
26.6 \\
26.9 \\
25.7 \\
26.1 \\
27.1 \\
27.2 \\
26.3 \\
25.3
\end{tabular} & $\begin{array}{l}\text { CARR } \\
\text { ALCA } \\
\text { ALCI } \\
\text { BAST } \\
\text { CAMP } \\
\text { FRIT } \\
\text { HERE } \\
\text { MART } \\
\text { IRON }\end{array}$ & \begin{tabular}{|c|}
$m m . H g$ \\
26.4 \\
27.4 \\
27.3 \\
24.0 \\
26.6 \\
27.6 \\
27.8 \\
27.1 \\
27.7
\end{tabular} & $\begin{array}{l}\text { FW } \\
\text { WAB } \\
\text { BH } \\
\text { WM } \\
\text { EJ } \\
\text { TB } \\
\text { MA } \\
\text { PB }\end{array}$ & $\begin{array}{l}m m . \mathrm{Hg} \\
26.4 \\
27.7 \\
24.7 \\
28.0 \\
24.0 \\
24.8 \\
25.5 \\
26.8\end{array}$ \\
\hline Mean & 26.92 & Mean & 26.26 & Mean & 26.88 & Mean & 25.99 \\
\hline
\end{tabular}

II is the resultant of at least 3 tonometric equilibrations by the standard analytical method of Van Slyke. In the series from Dill and others (19), $\mathrm{pH}$ was calculated and checked by the glass electrode. The means for the 4 series are in excellent agreement, especially when the difficulty of the estimation is considered. In the combined series the extremes are 24.0 and 28.2, with a grand average of 26.52 .
In the present series of normals from The Mayo Clinic, there are sufficient data to define the position of the dissociation curve over the range 40 to 70 per cent in 8 cases and to 80 per cent in 6 of these; in addition, there are a few acceptable figures for 30 and 90 per cent saturation. Those values are summarized in Table III.

TABLE III

Partial pressure of oxygen $\left(\mathrm{pO}_{2}\right)$ required to give 30,40,50, $60,70,80$, and 90 per cent saturation of human blood at $p H_{c}=7.10, T .=37.5^{\circ} \mathrm{C}$.

\begin{tabular}{|c|c|c|c|c|c|c|c|}
\hline Subject & $\begin{array}{c}30 \text { per } \\
\text { cent }\end{array}$ & $\begin{array}{l}40 \text { per } \\
\text { cent }\end{array}$ & $\begin{array}{c}50 \text { per } \\
\text { cent }\end{array}$ & $\begin{array}{c}60 \text { per } \\
\text { cent }\end{array}$ & $\begin{array}{c}70 \text { per } \\
\text { cent }\end{array}$ & $\begin{array}{l}80 \text { per } \\
\text { cent }\end{array}$ & $\begin{array}{l}90 \text { per } \\
\text { cent }\end{array}$ \\
\hline & $\underset{H g}{m m}$. & $\operatorname{mm}_{\mathrm{Hg}}$ & $\operatorname{mm}_{\mathrm{Hg}}$ & $\underset{H \boldsymbol{g}}{\operatorname{mm} .}$ & $\underset{H g}{m}$. & $\underset{H \boldsymbol{g}}{\mathrm{mm}}$ & $\underset{H \boldsymbol{g}}{\operatorname{mm}}$ \\
\hline
\end{tabular}

NORMALS

\begin{tabular}{l|l|l|l|l|l|l|l}
\hline FW & & 23.8 & 26.4 & 29.7 & 34.3 & 41.5 & \\
WAB & & 23.4 & 27.7 & 33.0 & 39.4 & 48.0 & \\
BH & & 21.7 & 24.7 & 28.5 & 33.5 & 40.0 & \\
WM & & 25.2 & 28.0 & 31.6 & 36.0 & 41.2 & \\
EJ & & 20.2 & 24.0 & 28.7 & 35.0 & 44.0 & 58.5 \\
TB & 17.3 & 20.9 & 24.8 & 28.8 & 34.5 & 43.0 & 60.0 \\
PB & & 22.2 & 26.8 & 32.6 & 40.0 & & \\
MA & & 22.0 & 25.5 & 30.2 & 36.4 & & \\
Mean & $(17.3)$ & 22.42 & 25.99 & 30.39 & 36.14 & 42.95 & $(59.3)$ \\
\hline
\end{tabular}

LIVER DISEASE

\begin{tabular}{c|c|c|c|c|c|c|c}
\hline 1 & 20.4 & 24.0 & 28.0 & 33.1 & 40.0 & & \\
2 & 20.3 & 25.6 & 29.4 & 35.8 & 42.0 & 51.5 & \\
3 & & 25.2 & 28.0 & 31.8 & 38.0 & 46.5 & 57.0 \\
4 & & 26.9 & 30.9 & 35.6 & 41.5 & 50.2 & 65.0 \\
5 & & 25.6 & 29.1 & 33.4 & 38.6 & & \\
6 & & 24.4 & 27.8 & 31.9 & 37.2 & 44.8 & \\
7 & & 26.4 & 29.8 & 34.0 & 39.6 & 46.5 & \\
8 & & 24.2 & 26.8 & 31.8 & & & \\
10 & & 24.0 & 28.8 & 35.5 & & & \\
12 & & 22.0 & 25.0 & 29.0 & & & \\
13 & & 26.0 & 29.0 & 35.0 & & & \\
\hline Mean & 20.4 & 24.81 & 28.34 & 33.20 & 39.56 & 47.90 & 61.0 \\
\hline
\end{tabular}

Position of the oxygen dissociation curve in liver disease

Figure 3 shows the logarithmic plots of $\mathrm{pO}_{2}$ against per cent saturation and against $\mathrm{pH}$ for constant saturations in a typical case of advanced cirrhosis in the liver. The data for 12 cases of liver disease are summarized in Table III. There can be no doubt that, other things being equal, the position of the oxygen dissociation curve in severe hepatic disease is definitely displaced to the right, that is, the oxygen affinity of the blood is reduced. This is true not only of the half saturation level, 


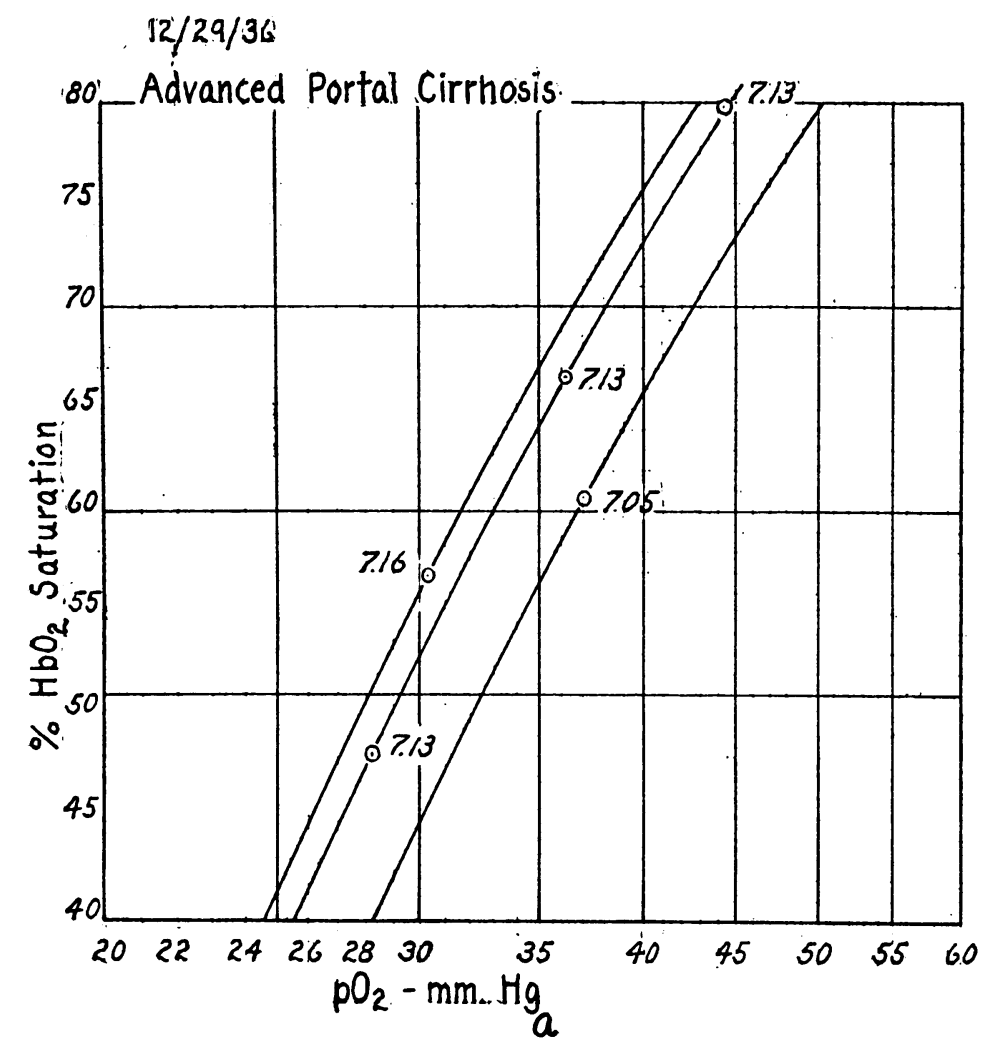

$\mathrm{pH}_{c} \quad$ J.R. Advanced Portal Cirrhos15

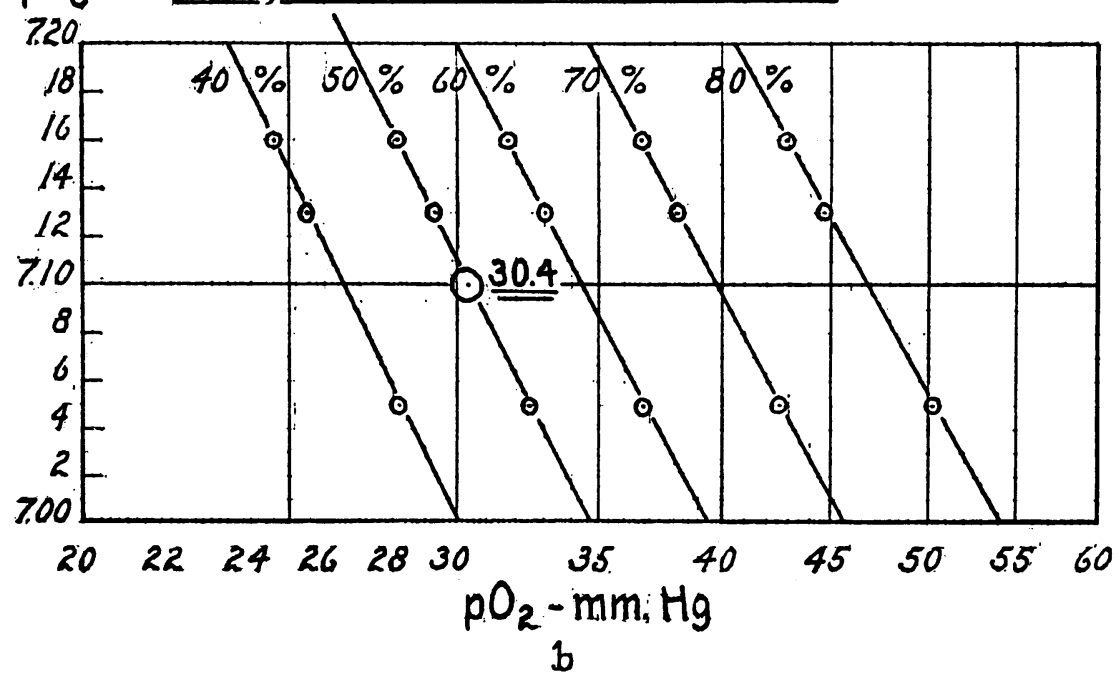

Fig. 3. Oxygen Dissociation Curves of Whole Blood of Patient with Advanced Cirrhosis of the Liver

$a$, Plot of $\log \mathrm{pO}_{2}$ against per cent of oxygen saturation; values of $\mathrm{pH}_{\mathrm{c}}$ are given alongside the determined points; and $b$, Plot of $\log \mathrm{pO}_{2}$ against $\mathrm{pH}_{\mathrm{c}}$ for oxygen saturations $40,50,60,70$ and 80 per cent. 

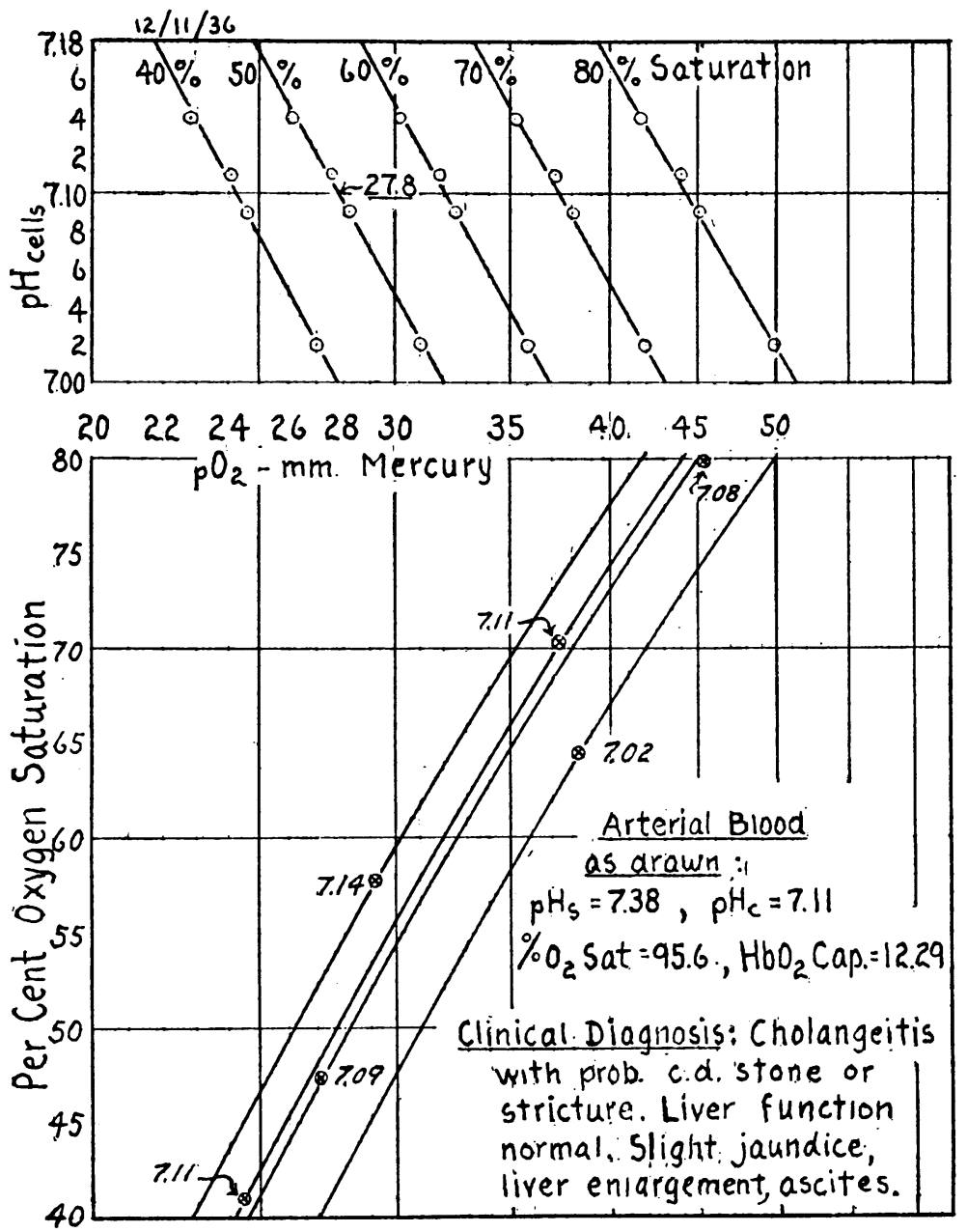

Fig. 4. Oxygen Dissociation Curves of Whole Blood of a Patient with a Previously Repaired Stricture of the Common Duct and Recent Cholangeitis-Hepatic Damage Minimal

Plots of $\log \mathrm{pO}_{2}$ against per cent of oxygen saturation and against $\mathrm{pH}_{\mathbf{c}}$.

but also over the whole of the curve which has been explored so far (Figure 4).

There are four possible explanations of the abnormality of the oxygen dissociation curve noted in these cases. These may be listed briefly: (1) excessive instability of the hemoglobin, (2) a greatly reduced rate of reaction of the hemoglobin with oxygen, (3) an abnormal ion distribution between cells and plasma, and (4) an alteration of the fundamental affinity between the hemoglobin and oxygen. We have not been able to rule out any of these possibilities with absolute certainty, but experimental evidence is opposed to the first three possibilities.
Excessive instability of the hemoglobin might conceivably result in a differential effect, so that more hemoglobin would be decomposed in the tonometry at $37.5^{\circ} \mathrm{C}$. than in the determination of oxygen capacity at room temperature. However, the values for oxygen capacity obtained from equilibration at $37.5^{\circ} \mathrm{C}$. checked those obtained at room temperature. When hemoglobin is inactivated spontaneously, methemoglobin is formed; we found no appreciable formation of methemoglobin in these bloods, even when determinations were made at the end of the day's tonometry. Moreover, the oxygen capacity values in all cases agreed within the limits of error 
with the estimation of total hemoglobin by the photelometer method of Sanford, Sheard and Osterberg (20).

So far, it would seem that a difference in the stability of the blood from the patients with liver disease could be ruled out. Such blood does, however, exhibit one peculiarity worthy of mention; it has a considerably increased metabolism, as measured by the rate of oxygen uptake of the blood when allowed to stand at room temperature. This was consistently demonstrated also with blood from dogs whose livers had been damaged by repeated administration of toluendiamine. It is probable that the increased number of leukocytes in these bloods is responsible.

An alteration in the rate of reaction of the hemoglobin with oxygen might mean that the ordinary time allowed for tonometric equilibration would be insufficient. In more than 20 tonometers we increased the time for equilibration from 20 to about 30 minutes but did not find that any additional oxygen was absorbed by the blood.

An abnormal distribution of ions between cells and plasma would be apt to lead to an error in the calculations of the $\mathrm{pH}_{\mathrm{c}}$, even if the $\mathrm{pH}_{\mathrm{s}}$ (plasma or whole blood $\mathrm{pH}$ ) were directly determined. In a number of cases we have analyzed cells and plasma, separated under oil at $0^{\circ} \mathrm{C}$., after tonometric equilibration. No gross abnormalities in the distribution of either chloride or bicarbonate were revealed.

Theoretically, at least, it might be preferable to eliminate all calculation of $\mathrm{pH}_{\mathrm{c}}$ by working with laked blood. This we have done in 7 experiments. The blood was laked by freezing and thawing several times without allowing its temperature to rise above $25^{\circ} \mathrm{C}$. at any time before tonometry. The $\mathrm{pH}$ of the laked blood (equivalent to $\mathrm{pH}_{\mathrm{c}}$ in whole blood) was measured by the glass electrode. This method has the disadvantage that we were never able to prevent a slight loss of oxygen capacity during laking, but in no case did we find any certain difference in the position of the dissociation curve of the laked blood as compared with the whole blood at the calculated $\mathrm{pH}_{c}$ In two cases the curves on the laked blood were to the left of those obtained on the same blood before laking, but the difference was scarcely beyond the experimental error, and even the dissociation curves on the laked blood were to the right of the average for normal blood. It is possible that this work should be extended if the present technical difficulties can be overcome, but the results so far do not lend much promise to the prospect of finding the solution to the peculiarities of these bloods in this way.

At the present time we are forced to the tentative conclusion that either the fundamental affinity of the hemoglobin for oxygen is reduced in these cases of liver disease, or that several of the other possibilities are operating together, so that their combined effect exceeds the limits of error that we have established for them separately. It should be noted that, in spite of the uncertainty as to ultimate site of the peculiarity of the blood in liver disease, the fact is firmly established that the physiological oxygen dissociation curve is abnormal and that the affinity of the blood for oxygen is reduced even at constant $\mathrm{pH}_{\mathrm{s}}$.

\section{SUM MARY}

The present study confirms the presence of oxygen unsaturation of the arterial blood in advanced cirrhosis. A study of the oxygenhemoglobin combination in such cases, with measurement of $\mathrm{pH}_{\mathrm{s}}$ and $\mathrm{pH}_{\mathrm{c}}$ of the arterial blood as drawn and as equilibrated, shows an apparent decreased affinity of hemoglobin for oxygen. This decreased affinity persists over a range of from 30 to 80 per cent saturation and is sufficient to account for the observed anoxemia.

\section{BIBLIOGRAPHY}

1. Snell, A. M., The effects of chronic disease of the liver on the composition and physicochemical properties of blood: changes in the serum proteins; reduction in the oxygen saturation of the arterial blood. Ann. Int. Med., 1935, 9, 690.

2. Judd, E. S., Snell, A. M., and Hoerner, M. T., Transfusion for jaundiced patients. J. A. M. A., 1935, 105, 1653.

3. Henderson, L. J., Bock, A. V., Dill, D. B., Hurxthal, L. M., and van Caulaert, C., Blood as a physicochemical system. VI. The composition and respiratory exchanges of human blood in terminal chronic nephritis. J. Biol. Chem., 1927, 75, 305.

4. Dill, D. B., Bock, A. V., van Caulaert, C. Fölling, A., Hurxthal, L. M., and Henderson, L. J., Blood as a physicochemical system. VII. The composition and respiratory exchanges of human blood 
during recovery from pernicious anemia. J. Biol. Chem., 1928, 78, 191.

5. Dill, D. B., Bock, A. V., Lawrence, J. S., Talbott, J. H., and Henderson, L. J., Blood as a physicochemical system. VIII. Diabetic coma. J. Biol. Chem., 1929, 81, 551.

6. Keys, Ancel, Hall, F. G., and Barron, E. S. G., The position of the oxygen dissociation curve of human blood at high altitude. Am. J. Physiol., 1936, $115,292$.

7. Dill, D. B., Daly, C., and Forbes, W. H., The pK' of serum and red cells. J. Biol. Chem., 1937, 117, 569.

8. Keys, Ancel, The microdetermination of chloride in biological materials. J. Biol. Chem. (In press.)

9. Keys, Ancel, The determination of total base in blood and other biological fluids by the electrodialysis method of Adair and Keys. J. Biol. Chem., 1936, $114,449$.

10. Barcroft, J., The Respiratory Function of the Blood. University Press, Cambridge, 1914.

11. Lundsgaard, C., Studies of oxygen in the venous blood. I. Technique and results on normal individuals. J. Biol. Chem., 1918, 33, 133.

12. Lundsgaard, Christian, Studies of oxygen in the venous blood. II. Studies of the oxygen unsaturation in the venous blood of a group of patients with circulatory disturbances. J. Exper. Med., 1918, 27, 179.

III. Determinations on five patients with compensated circulatory disturbances. Ibid., 1918, 27, 199.

IV. Determinations on five patients with incom- pensated circulatory disturbances. Ibid., 1918, 27, 219.

13. Lundsgaard, Christian and Möller, Eggert, Investigations on the oxygen content of cutaneous blood (so called capillary blood). J. Exper. Med., 1922, 36, 559.

14. Bock, A. V., Field, H., Jr., and Adair, G. S., The oxygen and carbon dioxide dissociation curves of human blood. J. Biol. Chem., 1924, 59, 353.

15. Bock, A. V., Dill, D.B., Hurxthal, L. M., Lawrence, J. S., Coolidge, T. C., Dailey, Mary E., and Henderson, L. J., Blood as a physicochemical system. V. The composition and respiratory exchanges of normal human blood during work. J. Biol. Chem., 1927, 73, 749.

16. Peters, J. P., and Van Slyke, D. D., Quantitative Clinical Chemistry. Vol. I. Interpretations. Williams and Wilkins Co., Baltimore, 1931, p. 570.

17. Talbott, J. H., Edwards, H. T., Dill, D. B., and Drastich, L., Physiological responses to high environmental temperature. Am. J. Trop. Med., 1933, 13, 381.

18. Keys, Ancel, Matthews, B. H. C., Forbes, W. H., and McFarland, R. A., Individual variations in ability to acclimatize to high altitudes. Proc. Roy. Soc. London, (B). (In press.)

19. Dill, D. B., Edwards, H. T., Fölling, A., Oberg, S. A., Pappenheimer, A. M., Jr., and Talbott, J. H., Adaptations of the organism to changes in oxygen pressure. J. Physiol., 1931, 71, 47.

20. Sanford, A. H., Sheard, Charles and Osterberg, A. E., The photelometer and its use in the clinical laboratory. Am. J. Clin. Path., 1933, 3, 405. 